\title{
Attitude of Undergraduate Youths of Democratic Values: Implication for Social Studies
}

Lucky Omoede, Aimiyekagbon

\author{
Department of Educational Psychology and Curriculum Studies, \\ Faculty of Education, University of Benin, Benin City, Nigeria \\ E-mail: omoede.aimiyekagbon@uniben.edu
}

\section{Rasak Okunzuwa, Uzamere}

Department of Educational Psychology and Curriculum Studies, Faculty of Education, University of Benin, Benin City, Nigeria

\author{
Doi:10.5901/jesr.2014.v4n6p469
}

\begin{abstract}
An active citizen must ensure that government policies truly represent people's best interest and not those of a handful of rulers. Citizens are expected to play their functional role by seriously participating in the entire democratic process. But this decision to participate or not depends on their awareness, adherence and internalization of democratic values. This paper examined the extent to which Nigerian undergraduate youths are regulated by democratic ethos of equality (one-man-one vote), patriotism, honesty, respect, tolerance, rule of law, etc. while discharging their civic duties. To investigate the study, three research questions and two hypotheses were raised. The descriptive survey method was employed wherein 586 undergraduate youths from four universities in Edo State were sample for study using the purposive sampling techniques. Frequency count, percentages and t-test statistics were employed as analytical tools. At the end of analysis, the study concludes that undergraduate youths awareness, understanding, internalization and adherence to democratic values during civic practices is selective of institution types (whether public or private) but not selective of programmes (whether full-time or part-time). It was recommended among others that the majority of uneducated youths that has been noted for high level of incivility, undemocratic behaviours and attitudes in the various literature cited in this work be exposed to democratic values through Social Studies, Non-formal and Adult education programmes, all agencies such as National Orientation Agency(NOA), Independent National Electoral Commission (INEC), etc. and civil society groups.
\end{abstract}

\section{Introduction}

The success of democracy rest on the enlightenment, activeness and commitment of citizens and hence there must be active and informed involvement of the people at all levels of governance as willing participants in defining and maintaining their democracy (NOA, 2006). A democratic citizen should be concerned with promoting understanding of the ideals of democracy. The youths of any society are a potential force to reckon with in that society, Nigeria not exempted. They constitute a large chunk of the decision making groups in the society. Youths must not be unlookers but the driving force behind democracy and their participation must not be limited to elections only, but a continuing engagement with the process of democratic governance. They must ensure that government policies truly represent people's best interest and not those of a handful of rulers (NERDC, 2005).

So, for the youths to play their expected and functional role as democratic citizens there must be serious participation in the entire democratic process. The decision of the youths to participate or not to participate depends on their awareness, adherence and internationalization of these democratic values and this has serious consequences on democracy and the general polity. CIVITAS (1991) and Avaro (2001) defined democratic values "as the fundamental beliefs and constitutional principles which guide the democratic government put in place in a particular society". They are ethos that regulates the extent, level and involvement of participants in a democracy. Some of these values of Nigerian democracies are freedom, equality(one-man-one vote), justice, toleration of diversity, unity(national integration), national loyalty(as against sectional loyalty), rule of law, separation of powers, checks and balances, transparency, patriotism, dignity of human person, representative government, self-reliance, due process, electoral credibility(citizens vote must count), common good(acting in the best interest), popular consent, supremacy of the people, toleration of opposition and legitimacy (FRN, 1999; Ojo, 2003; NERDC, 2005 \& Nnamdi, 2009). They are in turn determined by the factors of or the interplay of political culture, civic or citizenship education and the political experiences of the society in question. 
The crux of this study is to find out the extent to which Nigerian youths imbibed or are regulated by democratic values while discharging their civic duties.

Ojo (2003) advanced that "the lack of development of democratic attitude (values) is one major obstacle that has mar democratic consolidation in Nigeria. Thus, it is the obstacle to youth positive participation in our democracy". And that "both the elites and youths have surprisingly shown weak commitment to basic symbols and values of democracy". Hence, there is serious manifestation of greed, inordinate ambition to win power, thuggery, dishonesty, personalization of political/public offices, insincerity, disrespects for others, intolerance, etc. in our national polity. All these undemocratic behaviours manifest in the forms of electoral rigging; kidnapping/killing of political opponents; writing or sponsoring the publications of damaging articles in our media; tearing, removal or defacing of posters belonging to political opponents/parties; youths enlisting into various cut groups to be used as party kingpins/political thugs; general apathy/indifference of many youths to elections and democratic process; youths mortgaging their conscience after being induced with meager amount of money or materials like face-caps, T-shirts, umbrellas etc. (Aghayere, 2007 and Omorogbe \&Orobor, 2007) to support the wrong candidates/parties knowing fully well they have no political will and the reputation to deliver on electoral promises and thereafter put their future in jeopardy and perpetual wants. The end result is bad leadership/governance, high number of electoral cases in court, lack of basic infrastructure, unemployment, and underemployment.

There is no doubt that Nigerian youths have contributed immensely to the growth and development of this country, Nigeria. Their struggle and move have always been a sacrificial one which outcomes is not only their selfish interest alone but for the generality of the people (Aghayere, 2007). Youths have been involved in the evolution of democracy and advocacy/entrenchment of good governance and creation of civil society groups in Nigeria. But the many years of military rule in Nigeria have been marred by uncivil political behaviours that ranged from political apathy to electoral fraud. The attendant effect has been lack of popular participation, and disengagement of many Nigerians, particularly youths, from political processes. These developments negate the role of citizens in a democracy according to Gatson (2001) where he argued that "in a representative system, citizens need to develop the capacity to evaluate the talents, character, and performance of public officials. This, he says, a democratic state demands from her citizens" and this suggest weak civil support for democratic values and institutions.

So, for any democracy to be sustained, it is essential that its citizenry, mostly youths, possess the requisite skills, demonstrate the above mentioned values, and display the behaviours that accord democracy (NOA, 2006). But in Nigeria, the reverse has been the case among many youths. To participate and do so well in democratic activities, the youths must possess a good grasp of democratic values which will aid, guide and direct their conducts in the discharge of their civic responsibilities. That is, democracy is nurtured and sustained only when democratic values are rooted in the minds and actions of citizens (NOA, 2006).

NOA (2006) avers that, "the disposition that form democratic ethos are not inherited or passed down through the genetic mode, it is required that each generation of society learn civic facts, explore democratic ideas and values, and connect such concepts to the responsibility of citizenship. Such disposition must be fostered and internalized by word, study and by power of example." It is in this regard social studies as a school subject and a programme of society to mold the character of its youths in the direction it deems favourable to its democratic governance and survival is imperative.

\subsection{Statement of Problem}

From experience with youths during elections and others civic activities, the extent to which youths are aware of, understand and/or have internalized these values is not certain. There is apprehension when one takes a cursory look at the undemocratic attitudes, level of incivility prevalence among our youths and the ultimate manifestation of negative behaviours in our democracy. With the above scenario, what can we say about the present attitude of Nigerian youths toward democratic values? How much does social studies have to offer in promoting these values in the youths?

\subsection{Purpose of the Study}

This study aims specifically at finding out the attitude of youths toward:

1. The virtues of respect and tolerance while indulging in/carrying out political activities;

2. The virtues of honesty and patriotism while discharging their civic duties;

3. The principle of one-man-one vote in the political process. 
To conduct this study three research questions and two hypotheses were raised:

1. What is the attitude of youths to the virtues of respect and tolerance in the political process?

2. What is the attitude of youths to the virtues of honesty and patriotism in the democratic process?

3. What is the attitude of the youths to the principle of one-man-one vote in the political process?

\subsection{Hypotheses}

1. The attitude of students in public universities of democratic values does not differ significantly from those of the private universities.

2. The attitude of full-time students of democratic values does not differ significantly from those of part-time students.

\section{Method and Procedure}

In this study, the survey research design, using the descriptive method was employed. To collect the data for the research work, the researcher narrowed the study to undergraduate students of Edo state and made use of four universities in the state wherein the undergraduate in the state can be located. Six hundred undergraduate youths were sampled from the four universities in the state employing the simple random sampling technique. The four universities were made up of the two public universities, the university of Benin, Benin City and Ambrose Ali university, Ekpoma; and two private universities, Igbinedion university, Okada and Benson Idahosa university, Benin City. One hundred and fifty subjects were sampled from each of the university. These 150 subjects sampled from each of the university composed of 75 full-time and 75 part-time students except in Igbinedion university where there are no part-time students as at the time of this study. In it stead, 75 part-time students were sampled from Benson Idahosa university to allow for equal proportion of part-time and full-time students. It then means that, Igbinedion University had overall 75 students while Benson Idahosa university had 225 students.

A questionnaire designed by the researchers using the Likert format of four scaled response mode of Strongly Agree(SA), Agree(A), Disagree(D) and Strongly Disagree(SD) was utilized for the study. It was tagged, "Students' Attitude Toward Democratic Values Questionnaire"(SATDVQ). The questionnaire was content validated and the reliability was also tested for using the Crombach Alpha technique and a coefficient of 0.72 was obtained which is an indication of a good and reliable instrument. Of the 600 questionnaire administered it was 586 that was recovered. The collected data were analyzed using frequency count, percentages and t-test of independent sample as statistical tools.

\section{Results}

\subsection{Testing of Research Questions}

Research Question 1: What is the attitude of youths to the virtues of respect and tolerance in the political process? In order to test this research question, questionnaire items (QI) 1, 2 and 3 were used. The responses of respondents of the four universities to the above Qls as analyzed in Table 1 are presented and summarized in the table below. Thus:

Table 1: Youths Responses to the variables on the virtues of Respect and Tolerance in the political process

\begin{tabular}{|c|l|c|c|c|c|}
\hline QIs & Items Description & $\begin{array}{c}\text { Positive } \\
\text { Responses }\end{array}$ & $\begin{array}{c}\text { Negative } \\
\text { Responses }\end{array}$ & $\begin{array}{c}\text { +ve \% } \\
\text { Responses }\end{array}$ & $\begin{array}{c}\text {-ve \% } \\
\text { Responses }\end{array}$ \\
\hline 1 & $\begin{array}{l}\text { Tolerance of our diversity in terms of ethnicity, religion, cultural } \\
\text { differences, party ideology during the discharge of our civic duties } \\
\text { is a virtue needed by youths for proper participation. }\end{array}$ & 547 & 39 & 93.3 & 6.7 \\
\hline 2. & $\begin{array}{l}\text { Respecting the rights and interests of others during public } \\
\text { discussions, debates and decisions making is a virtue of tolerance } \\
\text { youths need to participate well in democracy }\end{array}$ & 568 & 18 & 96.9 & 3.1 \\
\hline 3. & $\begin{array}{l}\text { Tolerance for opposition and acceptance of electoral defeat is a } \\
\text { virtue needed by youths to promote peace in democracy. }\end{array}$ & 538 & 48 & 91.8 & 8.2 \\
\hline
\end{tabular}

Table 1 above reveals that the responses of respondents utilized in answering research question 1 (RQ1) shows 
overwhelming support or agreement with the items. The smallest been 538 (representing 91.8\%) as against 48(representing 8.2\%), the highest against or that disagreed with the RQ.

Decision: It therefore holds that, youths hold in high esteem the virtues of respect and tolerance why carrying out their civic activities.

Research Question 2: What is the attitude of youths to the virtues of honesty and patriotism in the democratic process? To test this research question, QIs 4, 5 and 6 were utilized.

The analysis of respondents' responses to these items is presented in Table 2 below:

Table 2: Youths Responses to the variables on the virtues of Honesty and Patriotism in the Democratic Process

\begin{tabular}{|c|c|c|c|c|c|}
\hline Qls & Items Description & $\begin{array}{c}\text { Positive } \\
\text { Responses } \\
\end{array}$ & $\begin{array}{c}\text { Negative } \\
\text { Responses }\end{array}$ & $\begin{array}{c}\text { +ve \% } \\
\text { Responses } \\
\end{array}$ & $\begin{array}{c}\text {-ve \% } \\
\text { Responses } \\
\end{array}$ \\
\hline 4 & $\begin{array}{l}\text { Patriotism, love for one's country, is a strong virtue needed by } \\
\text { youths to exercise their civic duties effectively. }\end{array}$ & 555 & 31 & 94.7 & 5.3 \\
\hline 5 & $\begin{array}{l}\text { Without a patriotic spirit no youth will commit his valuable time to } \\
\text { civic activities. }\end{array}$ & 545 & 41 & 93 & 7 \\
\hline 6 & $\begin{array}{l}\text { The use of falsehood and deception by youths to gain access } \\
\text { into elective offices destroy the virtue of honesty in our } \\
\text { democratic process. }\end{array}$ & 540 & 46 & 92.2 & 7.8 \\
\hline
\end{tabular}

Table 2 above reveals that the responses of respondents utilized in answering research question 2 (RQ2) shows overwhelming support or agreement with the items. The smallest been 540 (representing 92.2\%) as against 48(representing 7.8\%), the highest against or that disagreed with the RQ.

Decision: It therefore holds that, youths hold the virtues of honesty and patriotism in highest esteem why discharging their civic duties.

Research Question 3: What is the attitude of the youths to the principle of one-man-one vote in the political process? In order to answer this research question, QIs 7, 8 and 9 were used. The analysis of respondents responses to these QIs are presented below in table 3 , thus:

Table 3: Youths Responses to the Variables on the Virtue of One-man-one vote

\begin{tabular}{|c|c|c|c|c|c|}
\hline Qls & Items Description & $\begin{array}{l}\text { Positive } \\
\text { Responses }\end{array}$ & $\begin{array}{l}\text { Negative } \\
\text { Responses }\end{array}$ & $\begin{array}{c}\quad+v e \% \\
\text { Responses }\end{array}$ & $\begin{array}{c}\text {-ve \% } \\
\text { Responses }\end{array}$ \\
\hline 19 & $\begin{array}{l}\text { The principle of one-man-one vote is a virtue acceptable to the } \\
\text { youths because it helps to ensure the equality of citizens before } \\
\text { the law. }\end{array}$ & 560 & 26 & 95.6 & 4.4 \\
\hline 20 & $\begin{array}{l}\text { The principle of one-man-one vote helps to ensure that citizens' } \\
\text { vote count as such increase civic participation by youths. }\end{array}$ & 574 & 12 & 98 & 2 \\
\hline 21 & $\begin{array}{l}\text { One-man-one vote compels political office holders to be } \\
\text { accountable to the people and as such increases youth's } \\
\text { participation in civic activities. }\end{array}$ & 548 & 38 & 93.5 & 6.5 \\
\hline
\end{tabular}

Table 3 above reveals that the responses of respondents utilized in answering research question 3 (RQ3) shows overwhelming support or agreement with the items. The smallest been 548 (representing 93.5\%) as against 38(representing 6.5\%), the highest against or that disagreed with the RQ.

Decision: It therefore holds that, the youths hold in high esteem the principle of one-man-one vote why discharging their civic duties (exercising their franchise).

\subsection{Testing of hypotheses}

Hypothesis 1: The attitude of students in public universities of democratic values does not differ significantly from those of the private universities.

The table below illustrates the result of this analysis. 
Table 4: Computed t-test table for Public and Private Universities undergraduate students

\begin{tabular}{|c|c|c|c|c|c|c|}
\hline Universities & Mean & SD & Mean Difference & df & $T$ & P(Sig) \\
\hline Public & 14.568 & 2.242 & & & & \\
\cline { 1 - 2 } Private & 13.998 & 2.338 & 0.570 & 1170 & 4.037 & 0.034 \\
\hline
\end{tabular}

In the table above, the analysis reveals that the calculated t-test value of public university of democratic values when compared to those of private universities was 4.037; which is significant at 0.034 . Since the P-value of 0.034 is lesser than the alpha value of 0.050 , it therefore means that the null hypothesis is rejected

Decision: It therefore, holds that the attitude of students in public universities of democratic values differs significantly from those of the private universities.

Hypothesis 2: The attitude of full-time students of democratic values does not differ significantly from those of part-time students.

The table below illustrates the result of this analysis.

Table 5: Computed t-test table for Full-Time and Part-Time undergraduate Students

\begin{tabular}{|c|c|c|c|c|c|c|}
\hline Programme Types & Mean & SD & Mean Difference & Df & T & P(Sig) \\
\hline Full Time & 14.381 & 2.583 & & & & \\
Part-Time & 14.193 & 1.737 & 0.189 & 1170 & 1.563 & 0.072 \\
\hline
\end{tabular}

In the table above, the analysis reveals that the calculated t-test value of Full-time students of democratic values when compared to those of Part-time was 1.563; which is not significant at 0.072 . Since the P-value of 0.072 is greater than the alpha value of 0.050 , it therefore means that the null hypothesis is accepted.

Decision: It therefore holds that, the attitude of Full-Time students of democratic values do not differ significantly from those of Part-Time students.

\section{Discussion of Findings}

The finding from table 1 that shows the responses of youths to the variables on the virtues of respect and tolerance in the political process concludes that youths hold in high esteem the virtues of respect and tolerance why discharging their civic duties. Most of the respondents accept the need and are tolerance of our diversity in terms of ethnicity, religion, cultural differences and party ideology why carrying out their civic duties. This view point tends to negate what prevails in our society. Especially when one calls to mind the rate at which ethnic clashes, religious clashes/intolerance occurs in the north, party clashes during campaigns and electioneering in the country. The majority of respondents (96.9\%) also express their acceptance that respecting the rights and interests of others during civic activities like public discussions, debates and making decisions is part of tolerance imbibed by youths. The analysis also reveals that undergraduate youths accept the need and are tolerance of opposition and electoral defeat. But the clashes between oppositions, especially in politics where thugs and cultists are engaged to carryout various political killings and kidnappings and other dastardly acts negate this view points.

This finding and others below are very peculiar to undergraduates and negate the position of Ojo (2003) when he expressed that much of the deviance in political behaviour can be traced to the youths and are correctly attributed to the lack of a democratic attitude of mind... that both elite and youth have surprisingly shown weak commitment to basic symbols and values of democracy. The findings are influenced by their educational attainment or level of enlightenment. This goes to confirm what was posited by NOA (2006) that the disposition that forms democratic ethos are not inherited or passed down through the genetic mode... The disposition must be fostered and internalized by word, study and by power of example.

Table 2 that look at youths responses to the variables on the virtues of honesty and patriotism in the democratic process. The finding concludes that, youths hold in high regard the virtues of honesty and patriotism why discharging their civic duties. In it, patriotism was a strong virtue cherish by the youths as what can encourage the proper exercise of their civic duties. It was overwhelmingly agreed by the youths that without a patriotic spirit it is very difficult to sacrifice their precious time to civic activities. The youths also overwhelmingly agreed that honesty as a virtue, that is being truthful and sincere should be cherished and cultivated by youths. They condemned the habit of using deceptions and 
falsehood by youths to gain access into elective/political offices and regard it as capable of derailing the democratization process. This also goes to show that amongst the undergraduate youths these democratic values are being/have been internalized by them.

Table 3 illustrates youths' responses to the variables on the value of one-man-one vote. The finding concludes that youths hold in high esteem the principle of one-man-one vote in the political process why carrying out their civic duties. In it, it was found out that the principle of one-man-one vote is a value the youths have accepted into their life style why discharging their civic duties. When each citizen registers and votes once irrespective of personality, status and wealth, it helps to ensure equality of citizens before the law. One-man-one vote helps to ensure that citizens vote counts. This would prevent the government being in the hands of few selected wealthy businessmen and political godfathers and make the people representative accountable to the people and as such deliver dividend of democracy to the people. This in a nutshell will make the youths to have interest and zeal for civic activities.

The above findings goes to confirm that social studies teachings are having impact on undergraduates who have pass through its tutelage in the course of their academic carrier.

\section{Conclusion and Recommendations}

This study looked at the attitudes of undergraduate youths of democratic values and what would be the implication of the findings for Social Studies. From the findings, the following conclusions were drawn:

1. That undergraduate youths are aware, understand and have internalized/imbibed democratic values while indulging in civic activities.

2. That undergraduate youths place high priority on the democratic values of honesty, patriotism, respect, tolerance and one-man-one vote while carrying out their civic duties.

3. That undergraduate youths awareness, understanding, internalization and adherence to democratic values during civic practices is selective of institution types (whether public or private) but not selective of programmes (whether full-time or part-time).

Therefore, the researcher inferred that the learning experiences offered to learners as democratic values through social studies teachings have influenced and imparted them positively in the discharge of their civic duties.

Arising From the above, the following recommendations are therefore suggested:

1. As noted in this findings that the undergraduate youths imbibed democratic values while discharging their civic duties, and that the same cannot be said of other youths that are not as enlightened as the undergraduates. Hence, the serious level of incivility, undemocratic behaviours and attitudes noted in the various literature reviewed in this work. There should therefore be a serious and concerted effort to ensure that the Universal Basic Education (UBE) programme of free basic nine years education (Primary - JSS III) wherein Social Studies is offered as a compulsory subject, be made not only free but also compulsory for every child.

2. The literature review of this research work revealed that our core democratic value is constantly changing. More value recently has been added to our core democratic values as a result of changing social experiences and visions of our visionary leaders/presidents. Values such as transparency, due process, your vote must count, one-man-one vote etc are currently gaining access into Nigeria core values. These values need to as a matter of urgency be introduced into social studies curriculum.

3. All agencies, bodies or organizations such as INEC, NOA, etc, civil society groups and Non-Governmental Organizations should as a matter of national importance be seriously involved to help create the awareness, understanding and internalization of democratic values in Nigerian youths and political parties through workshops, seminars and public rallies. Since many has missed the opportunity of been imparted with democratic values through Social Studies teachings to reduce the acts of incivility constituted by uneducated youths.

4. Social studies curriculum should also be introduced to all non-formal education programmes such as Adult Education programme, where other categories of youths that do not attend the formal education can be targeted and inculcated with democratic values through such curriculum.

\subsection{Limitation of the study}

The researchers are not ignorant of the facts that it could be possible for some of the undergraduate youths (subjects) to deliberately distort or falsified the information supplied being aware they were under study. As such have pretended and 
have hidden their undemocratic behaviour and attitudes. So, this research work accepts the limitations these might have caused in terms of the results gotten, the conclusion and generalizations made.

\section{References}

Aghayere, V.O. (2003). Youths in the Democratization Process in Nigeria. In lyoha et al (Ed), Rethinking Governance and Development in the $21{ }^{\text {st }}$ Century. Ekpoma: Institute for Governance and Development.

Aghayere, V.O. (2007). Minimizing the Impact of Youths Restiveness and Cultism on April 2007 General Elections in Nigeria. International Journal of Governance and Development. 3(1), 43-51.

Avaro, J. (2001). The core democratic values. http://www.macomb.kiz.mi.us/cc/ cdv/cdv.htm. Accessed 23/01/2012.

Civitas (1991). Core values of America Constitutional Development. National Council of Social Studies Bulletin, Vol. 86.

Gatson, W. (2001). Political knowledge, political engagement, and civic education. Annual Review of Political Science. 4(1), 21-34.

FRN (1999). Nigeria Constitution. Abuja: Government press.

Nnamdi, H.S. (2009). Nigerian Government and Politics. Lagos: Trust Publications.

National Orientation Agencies (2006). Source Book on Civic Education. Abuja: NOA Printer.

National Educational Research and Development Council (2005). Voters Education. Abuja: NERDC Press.

Ojo, S.O.J. (2003). The Irony of Democracy and the Challenges of Democratic consolidation in Africa. In lyoha et al (Ed.), Rethinking Governance and Development in the 21st Century. Ekpoma: Institute for Governance and Development.

Omorogbe, S.K. and Orobor, M.E. (2007). Youths Negative Behaviours in the 2007 general elections: Temptations and consequences. International Journal of Governance and Development. 3(1), 32-40. 
ISSN 2239-978X

ISSN 2240-0524
Journal of Educational and Social Research MCSER Publishing, Rome-Italy
Vol. 4 No. 6 September 2014 